\title{
Biological, Serological, and Molecular Variability Suggest Three Distinct Polerovirus Species Infecting Beet or Rape
}

\author{
Sébastien Hauser, Mark Stevens, Christophe Mougel, Helen G. Smith, \\ Christiane Fritsch, Etienne Herrbach, and Olivier Lemaire
}

\begin{abstract}
First, sixth, and seventh authors: INRA, URVV, Vection et Lutte Intégrée, 28 rue de Herrlisheim, 68021 Colmar Cedex, France; second and fourth authors: IACR-Broom's Barn, Higham, Bury St. Edmunds, Suffolk, IP28 6 NP United Kingdom; third author: Université Lyon 1, Laboratoire d'Ecologie Microbienne, 43 Bd du 11 Novembre 1918, 69622 Villeurbanne Cedex, France; and fifth author: IBMP (CNRS), 12 rue du Genéral Zimmer, 67084 Strasbourg Cedex, France.
\end{abstract}

Accepted for publication 10 January 2000.

\begin{abstract}
Hauser, S., Stevens, M., Mougel, C., Smith, H. G., Fritsch, C., Herrbach, E., and Lemaire, O. 2000. Biological, serological, and molecular variability suggest three distinct polerovirus species infecting beet or rape. Phytopathology 90:460-466.

Yellowing diseases of sugar beet can be caused by a range of strains classified as Beet mild yellowing virus (BMYV) or Beet western yellows virus (BWYV), both belonging to the genus Polerovirus of the family Luteoviridae. Host range, genomic, and serological studies have shown

reading frame, ORF 0) are variable (about $30 \%$ homology). Based on these results, we propose a new classification of BMYV and BWYV into three distinct species. Two of these species are presented for the first time and are not yet recognized by the International Committee on Taxonomy of Viruses. The first species, BMYV, infects sugar beet and Capsella bursapastoris. The second species, Brassica yellowing virus, does not infect beet, but infects a large number of plants belonging to the genus Brassica within the family Brassicaceae. The third species, Beet chlorosis virus, infects beet and Chenopodium capitatum, but not Capsella bursa-pastoris.
\end{abstract} that isolates of these viruses can be grouped into three distinct species. Within these species, the coat protein amino acid sequences are highly conserved (more than $90 \%$ homology), whereas the P0 sequences (open
Additional keywords: Beta vulgaris, Brassica napus, host specificity, luteovirus, monoclonal antibody, phylogenetic studies, taxonomy.
Yellowing of beet can be caused by several viruses, especially those belonging to the genus Polerovirus of the family Luteoviridae (2). The genome of poleroviruses consists of a plus-sense, singlestranded RNA containing six open reading frames (ORFs). All members of the family Luteoviridae are phloem limited $(25,42)$ and circulatively (nonpropagatively) transmitted by several aphid species, including Myzus persicae.

The term "beet polerovirus" refers to sugar beet-pathogenic isolates of Beet mild yellowing virus (BMYV) and Beet western yellows virus (BWYV). BMYV was first reported by Russell (29) in Europe in 1958 as a disease affecting sugar beet. In 1960, Duffus (7) identified in North America a virus that caused yellowing on Lactuca sativa (lettuce), Spinacea oleracea (spinach), Raphanus sativus (radish), and Beta vulgaris (sugar beet). Initially named Radish yellows virus, the virus was renamed BWYV because of its importance in sugar beet. The discovery of BMYV in Europe and of BWYV in America led Duffus and Russell (9) to search for BWYV in Britain. Examination of weeds and crop plants such as lettuce showed that a BWYV-like virus was present in hosts previously reported to be immune to BMYV. These plants were shown to be infected with a virus resembling the American isolates in transmission characteristics and host range. In 1975, Duffus and Russell (10) conducted host range and serological studies with 12 BMYV isolates from English sugar beet crops. All produced a common reaction in certain indicator plants including sugar beet, Capsella bursa-pastoris (shepherd's purse), and Montia perfoliata. However, BMYV isolates failed to infect radish, lettuce, and Brassica napus (oilseed rape), which are known to be hosts of BWYV (8).

Corresponding author: O. Lemaire; E-mail address: lemaire@colmar.inra.fr

Publication no. P-2000-0228-02R

(C) 2000 The American Phytopathological Society
Moreover, a close serological relationship was also shown between the two poleroviruses using polyclonal antisera prepared against BWYV and BMYV $(10,15)$. These relationships impeded specific detection within plants or aphids and led to overinterpretation of the epidemiology and risk assessment of yellowing diseases due to these two viruses (18). Confusion still exists in the literature between BMYV and BWYV, and BMYV is still considered by some virologists to be a strain of BWYV.

In the last decade, several attempts have been made to differentiate BMYV and BWYV based on their host range. Host range studies by Stevens et al. (36) and Graichen and Rabenstein (16) have shown that BMYV infects a number of agronomically important European weed species, and its host range is narrower than that of European isolates of BWYV. Isolates of BMYV do not infect Brassica species. Similarly, European isolates of BWYV do not infect sugar beet. Based on these observations, Graichen and Rabenstein (16) concluded that BWYV and BMYV from Europe were two different virus species and proposed that Brassica-infecting isolates of BWYV should be renamed Turnip yellows virus (TuYV) (16).

Serologically, BMYV and BWYV cannot be distinguished by using either polyclonal antisera $(10,15)$ or most monoclonal antibodies (MAb) (11,26,33). However, MAb BYDV-PAV-IL-1, raised against Barley yellow dwarf virus-PAV (BYDV-PAV, genus Luteovirus), reacts with BMYV, but not with BWYV (3), and can be used to distinguish the two viruses in plants and aphids (34). However, Stevens et al. (37) recently showed that this antibody does not react with all isolates of BMYV, enabling identification of a second serotype of BMYV.

The comparisons of the nucleotide sequences of a BMYV isolate (BMYV-2ITB) (17) and a BWYV European isolate (BWYVFL1) (41) revealed important differences in the $5^{\prime}$ part of both genomic RNAs. Seven riboprobes that were synthesized to cover the 
full-length genome of the two beet poleroviruses $(19,21)$ confirmed this heterology within a wide range of BMYV and BWYV isolates, allowing specific detection of each viral species by nucleic acid hybridization. Recently, by sequence comparison of the RNA $5^{\prime}$ ends of 11 TuYV or BMYV isolates, Schubert et al. (32) showed that both viruses cannot be considered isolates of the same virus, as they did not share any common sequence motifs in this part of their genome. Moreover, sequence alignment of the $3^{\prime}$ end of the polymerase gene (ORF 2), the intergenic region, and the coat protein $(\mathrm{CP})$ gene (ORF 3) of various BMYV and BWYV isolates from beet, lettuce, and oilseed rape showed the existence of three groups of viruses $(4,5)$.

Studies conducted in several laboratories around the world have shown that beet polerovirus is composed of at least two distinct virus species, each composed of different strains, differing in their biological, serological, and genomic properties. To summarize the differences between these species and strains, we analyzed all available published data. However, these results have been obtained with various isolates studied within different experimental conditions. To clarify and improve the existing knowledge of the beet poleroviruses and to choose the most appropriate biological, serological, and molecular criteria for classification and distinction, we conducted a variability study in similar laboratory conditions and on isolates from our collection using host plants and antisera already described. Furthermore, we conducted phylogenetic studies on wellconserved sequences like ORF $3(4,5)$ and on a variable part of the genome-like ORF $0(25,32)$ on the same isolates to further understand the large complexity of beet poleroviruses.

This paper compares the biological, serological, and molecular properties of nine BMYV and six BWYV isolates collected from a number of countries. Based on these comparisons, we propose a new classification of beet poleroviruses in accordance with the recent proposals of D'Arcy and Mayo (2). This new classification will be submitted to the International Committee on Taxonomy of Viruses.

\section{MATERIALS AND METHODS}

Virus isolates. In this study, we used nine BMYV isolates originating from sugar beet; four BWYV isolates from sugar beet, oil- seed rape, Vicia faba (field bean), and lettuce, respectively; two TuYV isolates from oilseed rape; and one BWYV-Colorado isolate from sugar beet (Table 1). The two American isolates, BWYV-California and BWYV-Colorado, were kindly supplied by G. C. Wisler, USDA, Salinas, CA, and recently presented as being a probable new viral species, Beet chlorosis virus (BChV) $(22,23)$. The two TuYV isolates were kindly supplied by J. Schubert, Aschersleben, Germany. Isolates were maintained in host plants in a controlled environment at 20 to $25^{\circ} \mathrm{C}$ and transferred by serial transmissions using M. persicae (21).

Host plants. Host range comparisons were performed on key specific host plants, namely beet (Beta vulgaris cv. Trestel) and oilseed rape (Brassica napus cv. Jet 9). Graichen and Rabenstein (16) showed that these hosts enable distinction of BMYV isolates and BWYV European isolates, renamed TuYV. Capsella bursapastoris (shepherd's purse) was chosen for its ability to distinguish between the two strains of BMYV (37). Chenopodium capitatum was used because the second strain of BMYV and the new American strain of BChV, described by Lewellen et al. (22) and Liu et al. (23), induced severe reddening of leaves and because BWYV isolates do not infect this species $(9,27)$.

Virus transmission. A cloned population of $M$. persicae was reared on healthy pepper (Capsicum annuum), which is a plant species known to be immune to BMYV and BWYV. To inoculate test plants, aphids were given a 24-h acquisition access period on an infected source plant. Ten aphids were transferred to each healthy test plant for an inoculation access period of 4 days; the plants were then sprayed with an insecticide ( $4 \mathrm{ml}$ of mevinphos per liter). Infection of test plants was monitored 3 and 6 weeks later by triple-antibody sandwich (TAS)-enzyme-linked immunosorbent assay (ELISA) using MAb MAFF 24 (raised against BMYV-1 isolates from the United Kingdom), which is routinely used for detecting BMYV and BWYV, although it does not discriminate between them (33).

TAS-ELISA. TAS-ELISA was performed as previously described $(28,33)$. Leaves were ground in PBM buffer, composed of phosphate-buffered saline-Tween-polyvinylpyrrolidone with $0.1 \%$ dry milk, at 1/5 (wt/vol) dilution. MAb MAFF 24 was diluted at $1 \mu \mathrm{g} / \mathrm{ml}$ in PBM, and anti-rat alkaline phosphatase conjugate was used at 1/1,000 dilution. Optical density (OD) readings at $405 \mathrm{~nm}$ were

TABLE 1. Summary of the field, host range, serological, and sequence data for virus isolates used in this study

\begin{tabular}{|c|c|c|c|c|c|c|c|c|c|c|c|c|c|c|c|}
\hline \multirow[b]{2}{*}{ Virus isolates } & \multicolumn{3}{|c|}{ Isolate origin $^{\mathrm{a}}$} & \multirow[b]{2}{*}{ Biotype $^{b}$} & \multicolumn{4}{|c|}{ Host range ${ }^{c}$} & \multicolumn{3}{|c|}{ Serologyd } & \multicolumn{2}{|c|}{ Cluster $^{\mathrm{e}}$} & \multicolumn{2}{|c|}{ Accession number ${ }^{\mathrm{f}}$} \\
\hline & Plant host & Region, country & Year & & Beet & Rape & Caps & Chen & MAb1 & MAb2 & MAb3 & $\mathrm{CP}$ & P0 & ORF 3 & ORF 0 \\
\hline BMYV-2ITB & Sugar beet & Eure et Loire, F & 1980 & BSP & + & - & + & - & + & - & + & 5 & 1 & X83110 & X83110 \\
\hline BMYV-1 & Sugar beet & Suffolk, GB & 1997 & BSP & + & - & + & - & + & - & + & 5 & 1 & AF167474 & AF168598 \\
\hline BMYV-L & Sugar beet & Haut-Rhin, F & 1981 & BSP & + & - & + & - & + & - & + & 5 & 1 & AF167481 & AF168604 \\
\hline BMYV-J & Sugar beet & Haut-Rhin, F & 1990 & BSP & + & - & + & - & + & - & + & 5 & 1 & AF167480 & AF168603 \\
\hline BMYV-Iran & Sugar beet & Iran & 1992 & BSP & + & - & + & - & + & - & + & 5 & 1 & AF167479 & AF168602 \\
\hline BMYV-56r & Sugar beet & Suffolk, GB & 1996 & BSP & + & - & + & - & + & - & + & 5 & 1 & AF167482 & AF168599 \\
\hline BMYV-Colorado*g & Sugar beet & Colorado, USA & 1997 & $\mathrm{BnSP}$ & + & - & - & + & - & - & + & 3 & 3 & AF167483 & AF168607 \\
\hline BMYV-California* & Sugar beet & California, USA & 1996 & $\mathrm{BnSP}$ & + & - & - & + & - & - & + & 3 & 3 & AF167485 & AF168609 \\
\hline BMYV-56 & Sugar beet & Suffolk, GB & 1994 & $\mathrm{BnSP}$ & + & - & - & + & - & - & + & 4 & 3 & AF167476 & AF168605 \\
\hline BMYV-2a & Sugar beet & Suffolk, GB & 1997 & $\mathrm{BnSP}$ & + & - & - & + & - & - & + & 4 & 3 & AF167475 & AF 168610 \\
\hline BWYV-FL1 & Lactuca sativa & Vaucluse, F & 1977 & Und. & Und. & Und. & + & - & - & - & + & 1 & $2 \mathrm{~b}$ & X13063 & X13063 \\
\hline BWYV-Col & Oilseed rape & Haut-Rhin, F & 1986 & $\mathrm{Br}$ & - & + & + & - & - & - & + & 2 & $2 \mathrm{a}$ & AF167477 & AF168600 \\
\hline BWYV-Fev & Field bean & Haut-Rhin, F & 1986 & $\mathrm{Br}$ & - & + & + & - & - & - & + & 1 & $2 \mathrm{a}$ & AF167478 & AF168601 \\
\hline TuYV-BN5** & Oilseed rape & Gatersleben, D & nd & $\mathrm{Br}$ & - & + & + & nd & - & + & + & 1 & $2 \mathrm{a}$ & AF167484 & AF168606 \\
\hline TuYV-GB** & Oilseed rape & Norwich, GB & nd & $\mathrm{Br}$ & - & + & + & - & - & + & + & 1 & $2 \mathrm{a}$ & AF167486 & AF168608 \\
\hline
\end{tabular}

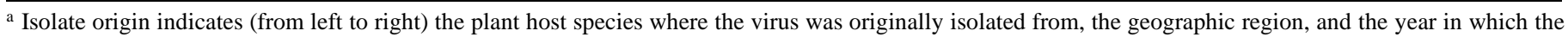
original field host was collected. For countries, $\mathrm{D}=$ Germany, $\mathrm{F}=$ France, $\mathrm{GB}=$ Great Britain, and USA $=$ United States.

b Biotype refers to the classification of isolates based on their host range.

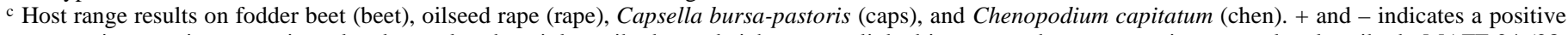
or negative reaction on an inoculated test plant by triple-antibody sandwich-enzyme-linked immunosorbent assay using monoclonal antibody MAFF 24 (28, 33). Undefined (Und.) means that BWYV-FL1M was previously described as being able to infect oilseed rape and beet (E. Herrbach and O. Lemaire, personal communication), but in this test, no infected oilseed rape was observed and few beets were infected with low optical density values. nd $=$ Not determined.

${ }^{\mathrm{d}}$ Positive (+) or negative (-) reactions have been assessed on isolates using monoclonal antibodies BYDV-PAV-IL-1 (MAb1), G4C10 (MAb2), and 3C2 (MAb3).

e Cluster indicates organization of coat protein (CP) and P0 amino acid sequences as presented in Figures 1 and 2.

f Accession number of GenBank for ORF 3 and ORF 0, except for BMYV-2ITB and BWYV-FL1 whose genomic RNA sequence has been published (17,40).

$\mathrm{g} *$ and $* *$ indicate isolates provided by G. Wisler and J. Schubert, respectively. 
taken after $0.5,1$, and $2 \mathrm{~h}$. Threshold values were deduced by calculating the mean of the OD values of six different healthy plants plus three times the standard deviation of these values. MAb BYDV-PAV-IL1 (3) and MAbs G4C10 (28) and 3C2 (12), provided by C. J. D'Arcy and F. Rabenstein, respectively, were used to determine the serological profile of the different isolates.

RNA extraction, cDNA synthesis, and polymerase chain reaction (PCR). Fresh leaf material $(100 \mathrm{mg})$ was ground in liquid nitrogen, and total RNA was isolated using PUREscript kit (Gentra Systems, Inc., Minneapolis, MN) according to the manufacturer's instructions. cDNA was synthesized from purified RNA, as described by Kotewicz et al. (20), and amplified by PCR (30). PCR reactions were carried out using a Hybaid Touchdown thermal cycler (Hybaid, Ltd., Teddington, Middlesex, England): 30 cycles of $30 \mathrm{~s}$ at $95^{\circ} \mathrm{C}, 45 \mathrm{~s}$ at $50^{\circ} \mathrm{C}$, and $60 \mathrm{~s}$ at $72^{\circ} \mathrm{C}$; followed by one cycle of $10 \mathrm{~min}$ at $72^{\circ} \mathrm{C}$. The primers used to amplify ORF 3 and ORF 0 of both beet polerovirus isolates are listed in Table 2 .

Cloning, sequencing, and phylogenetic analyses. Purified reverse-transcription (RT)-PCR products were cloned in $\mathrm{pSK}(+)$ Bluescript plasmid from PCR-Script Amp Cloning Kit (Stratagene Inc., La Jolla, CA), following the manufacturer's instructions. The clones were sequenced in both directions using the SequiTherm EXCEL II Long-Read DNA Sequencing Kit-LC (TEBU, le Perray en Yvelines, France) with IRD41-labelled primers (M13 reverse and M13 forward). The sequences were analyzed by the LI-COR DNA sequencer 4000 L (LI-COR, Lincoln, NE). Three clones for each ORF from each isolate were sequenced to ensure consistent and reliable sequence data.

Sequences were compared and analyzed using the ClustalX program (38) and PHYLIP 3.572 (13), and phylogenetic trees were drawn using neighbor-joining methods (31) or the PileUp program (6). To verify the statistical validity of the clusters obtained on the neighbor-joining tree, a bootstrap value was calculated on 1,000 trials. The nucleotide sequences were deposited in the EMBL nucleotide sequence database. The accession numbers are listed in Table 1.

\section{RESULTS}

Biological variability of BMYV and BWYV isolates. A standardized host range test, using key plant species previously shown to discriminate between BMYV and BWYV strains, was performed to study the biological variability of beet poleroviruses. Results are summarized in Table 1. The two American isolates, BWYVCalifornia and BWYV-Colorado, were known to induce severe reddening of $C$. capitatum leaves and interveinal yellowing of beet leaves with vein greening (22). Similar symptoms appeared when using the same hosts inoculated with BMYV-2a and BMYV-56 isolates from England. In our controlled conditions, BMYV-2ITB, BMYV-1, BMYV-L, BMYV-J, BMYV-Iran, and BMYV-56r isolates did not induce any symptoms on beet or $C$. capitatum.

The hosts range results revealed three distinct biotypes of virus as shown on Table 1. The first two biotypes (beet and shepherd's purse [BSP] and beet but not shepherd's purse [BnSP]) consist of virus isolates that do infect beet but not oilseed rape, hence corre- sponding to BMYV isolates. The third biotype (brassica specific $[\mathrm{Br}])$ consists of isolates that infect oilseed rape but not beet, including the BWYV European isolates and TuYV isolates. The results obtained in our host range study are consistent with those presented by Graichen and Rabenstein (16).

Biotype BSP includes isolates that infect shepherd's purse, but not $C$. capitatum, and corresponds to isolates formerly described as BMYV. Conversely, biotype BnSP is composed of isolates that are unable to infect shepherd's purse, but can infect $C$. capitatum; this biotype corresponds to BMYV European isolates (second strain) and the American isolates (BWYV-California and BWYV-Colorado) recently described, respectively, by Stevens et al. (37) and by Lewellen et al. (22) and Liu et al. (23).

Isolate BWYV-FL1 was previously described as being able to multiply weakly in beet and oilseed rape (E. Herrbach and O. Lemaire, personal communication). Under our experimental conditions, no oilseed rape and only $25 \%$ of inoculated beet (each having low absorbance values) became infected by BWYV-FL1. This was the only isolate exhibiting such a particular host range.

Serological properties. We attempted to correlate the biological and serological properties of the virus isolates using a panel of well-characterized MAbs.

MAb BYDV-PAV-IL-1 (3), raised against BYDV-PAV, recognized all BMYV isolates from sugar beet able to infect shepherd's purse. As could be expected from previous studies (37), no positive reactions were recorded with BWYV isolates.

MAb G4C10 (28), raised against BWYV, reacted here only with the German isolates of TuYV, thereby confirming previous results obtained with this MAb specific to the "second serotype" of BWYV from rape in Germany and France (28).

$\mathrm{MAb} 3 \mathrm{C} 2$, raised against BYDV-PAV, reacted with all beet polerovirus isolates under study, even with those previously reported as not recognizable by this $\mathrm{MAb}$, i.e., those detected using MAb G4C10 (12).

Molecular variability within ORF 0 and ORF 3. We sequenced two distinct parts of the genome to estimate the molecular variability of beet polerovirus isolates: ORF 3 , which encodes the $\mathrm{CP}$, and ORF 0 , which encodes a protein that could be involved in host range specificity $(24,40)$ and symptom expression (39). Alignments of the deduced amino acid sequences and phylogenetic trees (Figs. 1 and 2) were performed using the DNA analysis programs mentioned above. Reliability of the cluster organization was supported by bootstrap values, ranging from 91.4 to $100 \%$ on each cluster node in Figures 1 and 2. But for the $\mathrm{CP}$ amino acid sequence phylogenetic tree, the relationship between the clusters is not statistically significant (bootstrap value lower than 80\%). Except for the BWYV-FL1 CP amino acid sequence, we obtained the same cluster organization with each DNA alignment program, although there were differences in the relationship of isolates within clusters. This was due to the different ways the DNA alignment programs assess sequence information. Consequently, we observed only the composition of clusters and not the phylogenetical relation between isolates.

$\mathrm{CP}$ amino acid sequence variability was previously reported by de Miranda et al. (4), who characterized three groups of viruses.

TABLE 2. Sequences of primers used for reverse-transcription-polymerase chain reaction amplification

\begin{tabular}{|c|c|c|c|}
\hline Primer abbreviation & Sequence $5^{\prime}-3^{\prime}$ & Amplified sequence $^{\mathrm{a}}$ & Origin of sequence \\
\hline$\overline{\mathrm{CP}+}$ & ATG AAT ACG GTC GTG GGT AGG AG & ORF 3 of beet polerovirus isolates & BMYV-2ITB ${ }^{b}$ \\
\hline $\mathrm{CP}-$ & CCA GCT ATC GAT GAA GAA CCA TTG & ORF 3 of beet polerovirus isolates & \\
\hline BMORF0+ & ATG CAA TTT CAG CTT AAA ACA AAC A & ORF 0 of BMYV polerovirus isolates & BMYV-2ITB ${ }^{b}$ \\
\hline BWORF0+ & ATG CAA TTT CTC GCT CAC GCA AAC A & ORF 0 of BWYV and TuYV isolates & BWYV-FL1 ${ }^{\mathrm{c}}$ \\
\hline BWORF0- & TCA TAC AAA CAT TTC GGT GAT GAC & ORF 0 of BWYV and TuYV isolates & \\
\hline 2aORF0+ & ATG AAC TTT GAG ATT TGC TTC & ORF 0 of BMYV-2a and BMYV-56 isolates & BMYV-2a \\
\hline $2 \mathrm{aORF} 0-$ & TTA GGT CTC TCT ATG CAA ACT C & ORF 0 of BMYV-2a and BMYV-56 isolates & \\
\hline
\end{tabular}

${ }^{\mathrm{a}} \mathrm{ORF}=$ open reading frame, BMYV $=$ Beet mild yellowing virus, $\mathrm{BWYV}=$ Beet western yellows virus, and TuYV $=$ Turnip yellows virus.

${ }^{\mathrm{b}}$ Deduced from work by Guilley et al. (17).

${ }^{c}$ Deduced from work by Veidt et al. (41). 
However, the host range and serological data were incomplete, preventing exploration of the relationships between sequences and biological or serological properties. The $\mathrm{CP}$ sequence of the BMYV type member (BMYV-2ITB), for which the full genomic sequence was determined by Guilley et al. (17), was not included in study by de Miranda et al. Integration of the BMYV-2ITB CP sequence within the phylogenetic tree of de Miranda et al. (4) showed that this sequence did not belong to any cluster described in this paper. Contrary to the conclusions of de Miranda et al. (4), BMYV isolates should be classified into a distinct cluster. We built an additional phylogenetic tree with the CP amino acid sequences from our study and the consensus sequences determined for the three groups of de Miranda et al. (4) (Fig. 1, Grp 1, Grp 2, and Grp 3). The CP amino acid sequence of beet poleroviruses appears to be highly conserved; the weakest percentage of similarity amongst all CP sequences was $89.8 \%$ (ClustalX program). Five different clusters containing isolates sharing a minimum of $95 \%$ homology were observed within the phylogenetic tree (Fig. 1). According to our host range studies, all clusters corresponded to a single biotype of virus. The isolates belonging to the $\mathrm{Br}$ biotype were found in two different clusters: cluster 1 containing BWYV-Fev and TuYV isolates, and cluster 2 containing BWYV-Col isolates.

The BWYV-FL1 CP amino acid sequence was closer to cluster 2 when the analysis was performed by the PileUp program, as shown by de Miranda et al. (4,5). However, when comparisons were made by the ClustalX program, BWYV-FL1 was closer to cluster 1. Extensive analyses of the sequence homologies showed that the percentage of homology between BWYV-FL1 and Grp 1 or Grp 2 was identical (95.2\%). When the nucleotides were compared, the BWYV-FL1 $5^{\prime}$ end of ORF 3 was closer to Grp 1 and the ORF 3 $3^{\prime}$ end was closer to Grp 2. Although the association of BWYVFL1 with cluster 1 or 2 mainly depends on the method used for multiple alignment, it is clear that the BWYV-FL1 amino acid sequence is divergent from other BWYV isolates. It is noteworthy that, in both cases, BWYV-FL1 belongs to a cluster containing only $\mathrm{Br}$ biotype isolates.

Isolates of the BnSP biotype were divided into two clusters: cluster 3 earlier defined by de Miranda et al. (5) and containing the European isolates (BMYV-2a and BMYV-56) and a new cluster (cluster 4) containing the American isolates (BWYV-California and BWYV-Colorado). BMYV isolates from the BSP biotype formed a new cluster (cluster 5).

Phylogenetic analysis of the P20 amino acid sequence encoded by ORF 4 and overlapping with ORF 3 showed a similar cluster organization with few differences in the relationships between isolates. This reflects a similar evolution of the two proteins, with the location of ORF 4 within ORF 3 providing a significant constraint on the changes allowed within the $\mathrm{CP}$ gene. This selection pressure would reduce the ability of the viral $\mathrm{CP}$ to evolve and could explain the high rates of similarity between clusters of different biotypes.

Sequence variability on the $5^{\prime}$ ends of RNA of BMYV and TuYV isolates was conducted in a previous study by Schubert et al. (32), showing that these two virus species were split between two different clusters with faint sequence homology. Similar results were obtained by Guilley et al. (17) using dot-plot methods (6). We performed phylogenetic analyses of the P0 amino acid sequence using our collection of isolates to associate the variability of the $5^{\prime}$ end sequences with host range data and CP clustering (Fig. 2). Schubert et al.'s (32) consensus sequences did not entirely cover ORF 0; thus, it was not possible to incorporate them in our study, but we analyzed identical isolates (TuYV-BN5, TuYV-GB, BMYV-2ITB, and BWYV-FL1). Our P0 sequence data showed three clusters, corresponding to the three biotypes (BSP, BnSP, and Br) described above. However, the similarity within the P0 cluster (less than $25 \%$ identity) was significantly less than the similarity between the CP clusters (more than 89.8\%). Furthermore, the amino acid sequences were highly conserved within each P0 cluster (more than
$90 \%$ identity). Analysis of the amino acid consensus sequence between different $\mathrm{P} 0$ clusters showed that the three clusters correspond to three different proteins with no amino acid sequence motifs conserved between clusters. We found that cluster 1 contained isolates of BMYV from the BSP biotype and that cluster 2 contained BWYV and TuYV isolates from the Br biotype that did not infect beet. BWYV-FL1 differs from members of other clusters by about $20 \%$ within P0. Cluster 3 contained American and European isolates of the BnSP biotype. Our phylogenetic tree (Fig. 2) showed, for the first time, a close relationship between the sequence of P0 and the host range of the virus.

Similar results were obtained when the P1 N-terminal amino acid sequence encoded by part of ORF 1 overlapping with ORF 0 was compared with the $\mathrm{P} 0$ sequence (data not shown), reflecting a similar evolutionary pathway for P0 and P1.

\section{DISCUSSION}

The use of key beet polerovirus indicator species such as Capsella bursa-pastoris and $C$. capitatum allowed us to identify three distinct virus biotypes. Each biotype was found to correspond to one of the three clusters deduced from the amino acid sequence of P0. Amino acid sequencing of the CP gene (ORF 3) allowed identification of five clusters, each attributable to a single biotype of virus. MAb BYDV-PAV-IL-1 is commonly used to distinguish between BMYV and BWYV, although it does not detect the BnSP biotype. The BnSP biotype represents more than $10 \%$ of the BMYV iso-

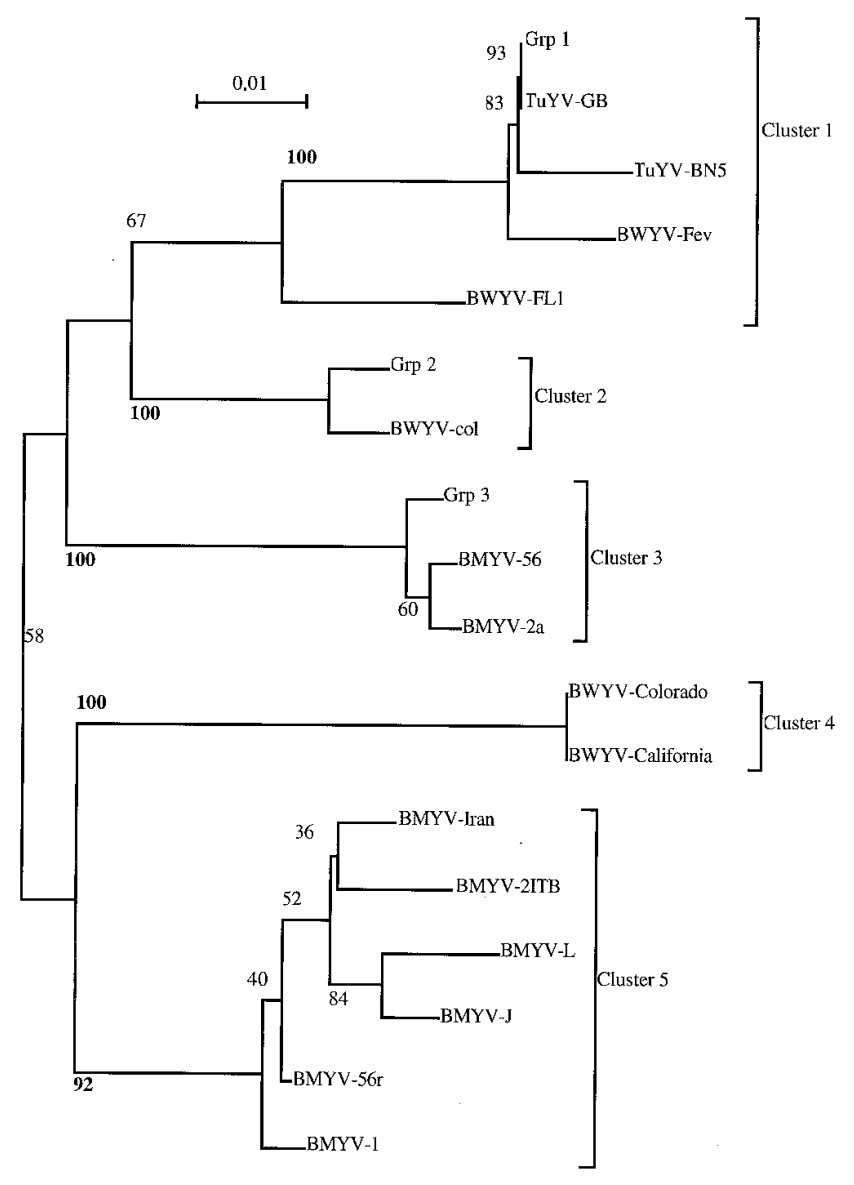

Fig. 1. Phylogenetic tree reconstructed by the neighbor-joining method (31) from the multiple alignment of 15 beet polerovirus coat protein amino acid sequences. Grp 1, Grp 2, and Grp 3 represent consensus sequences obtained by de Miranda et al. (4). The scale bar indicates distance in Kimura units, and bootstrap values are given on each cluster node. The five clusters are supported by bootstrap values (in bold), but relationships between clusters are not supported by bootstrap values. Within each cluster, isolates share more than $95 \%$ amino acid sequence homology. Minimum similarity observed is $90.4 \%$. 
lates found in the English sugar beet crop (37) and has been found in France and other European countries (35). As the three biotypes have less than $30 \%$ homology in the P0 sequence and have different serological properties, we propose to distinguish three distinct virus species within the BMYV isolates, TuYV and BWYV European isolates, and BWYV American isolates. The proposed species are as follows.

BMYV isolates from the BSP biotype are related when compared by their P0 (cluster 1) and CP (cluster 5) amino acid sequences. This BMYV species is also distinguishable from other beet poleroviruses using MAb BYDV-PAV-IL-1.

The name Brassica yellowing virus (BrYV) could be used to describe European isolates of BWYV, which does not infect beet but infects a large number of plant species belonging to the family Brassicaceae (16). TuYV, described by Graichen and Rabenstein (16), can be classified within the BrYV viral species because comparison of the $\mathrm{CP}$ and $\mathrm{P} 0$ sequences showed a close relationship to other BrYV isolates. However, MAb G4C10 distinguished TuYV from other BrYV, showing that TuYV should be considered a distinct serotype of BrYV, but not a different viral species. BWYVFL1 appears to be a particular strain differing within the P0 amino acid sequence by only 15 to $20 \%$ from other BrYV isolates and is able to infect fodder beet at a low rate when using $M$. persicae.
Although sequence and host range differences between BWYVFL1 and other BrYV isolates are sufficient to consider it a new species (2), we propose that BWYV-FL1 be considered a strain of BrYV. Most likely, BWYV-FL1 isolated from lettuce in 1977 and then maintained on Physalis floridana in Colmar (France) has evolved as a variant, losing its ability to infect or move into oilseed rape. Interestingly, the variability of $\mathrm{CP}$ amino acid sequences within members of BrYV is greater than that within BMYV members. This probably reflects the adaptation of isolates to different plant species and vectors, resulting in a broader host range of this viral species. This variability in the CP sequence may also explain the difficulties in raising a common MAb, which would cross-react with all BrYV and BWYV isolates.

The term BChV, suggested by Liu et al. (23) based on symptoms observed in infected beet in California, could be used to describe the American and European isolates from the BnSP biotype. Comparison of $\mathrm{CP}$ amino acid sequences showed that this species was composed of two clusters (Fig. 1): cluster 3, previously described by de Miranda et al. $(4,5)$ and corresponding to the European strain of $\mathrm{BChV}$, and cluster 4, corresponding to the American strain. The differences between the two strain clusters could be explained by the evolution of the viruses on different continents and in different environments. This pattern of geographically associated

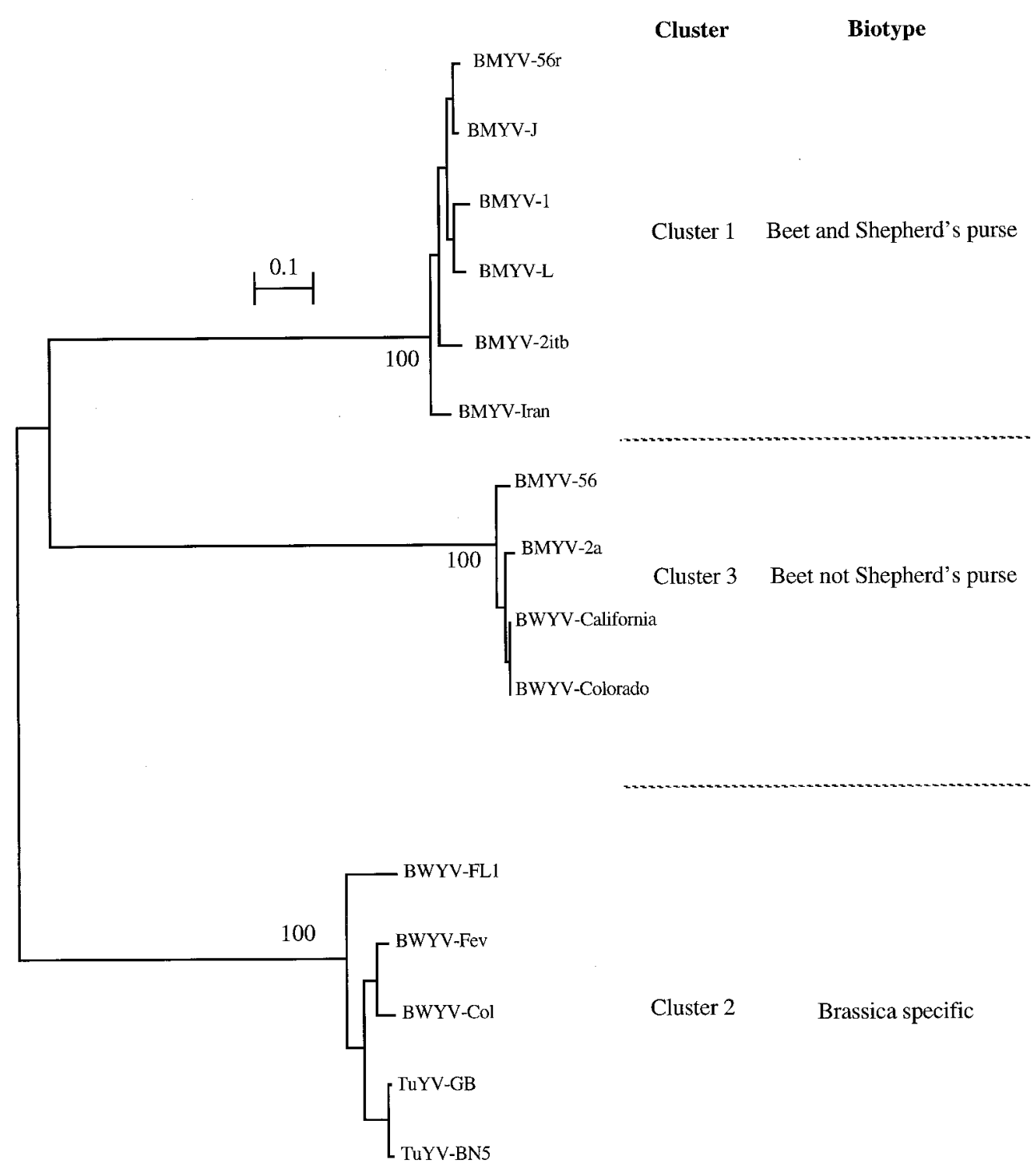

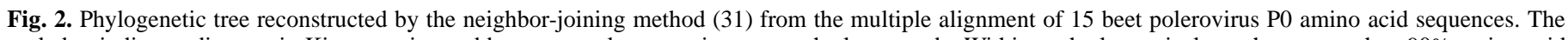

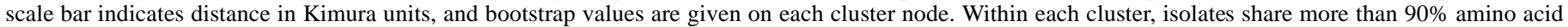
sequence similarity. Minimum similarity observed is $15.9 \%$. 
variation reflects the spatial and temporal isolation of the two viruses and their adaptation to different vector species and host plants. To date, no host range or vector specificity differences were found for these two strains of the BnSP biotype.

Determining the biological, serological, and molecular properties of different isolates under constant conditions has enabled us to better describe the key features of the beet polerovirus group. It would be of great interest to perform similar experiments with more American isolates of beet polerovirus to determine if different BWYV species exist and whether BMYV occurs in sugar beet crops in the United States.

Knowledge of the sequence diversity among isolates of BMYV and BWYV within P0 and P3 can be exploited to discriminate between the virus species by using specific primers for RT-PCR or restriction fragment length polymorphism procedures. The accurate and reliable characterization of these species could greatly improve epidemiological and risk assessment studies such as those conducted in the United States (18).

BWYV-FL1 is the only BWYV that has been fully sequenced (41), and an infectious clone was synthesized by Veidt et al. (40). However, this work has shown that BWYV-FL1 should be considered an atypical strain, as its biological and molecular properties were different from those of other BrYV isolates. There is a need to obtain a new full-length genomic RNA sequence from another well-characterized BrYV isolate to estimate these differences. This conclusion is important, since numerous studies are performed using the BWYV-FL1 strain.

The P0 amino acid sequence is highly variable among the three beet polerovirus species. Conversely, there is more than $90 \%$ homology within the $\mathrm{CP}$ amino acid sequences we studied, and we observed three clusters of the P0 sequence associated to five clusters of the CP sequence. Such incongruent lineage of two parts of the same genome suggests that beet poleroviruses appeared during evolution of the family Luteoviridae by recombination of RNA ancestors $(1,14)$. It has been suggested that members of the family Luteoviridae share a common ancestor in the $3^{\prime}$ region, but different ancestors in the $5^{\prime}$ part of the genome $(1,14)$. Variability within the 5 region of the viral RNA is strongly correlated to the different biotypes, indicating that the protein domain involved in controlling host range could be located in the $5^{\prime}$ region of the luteoviral genome. This hypothesis is supported by results obtained with BWYVFL1, since the CP amino acid sequence of BWYV-FL1 is similar to that of BrYV-GB (more than $95 \%$ homology), whereas only $81 \%$ homology was found for the $\mathrm{P} 0$ amino acid sequence; these two isolates show distinct biological properties in beet and oilseed rape.

\section{ACKNOWLEDGMENTS}

This project was supported by a CIFRE grant from SES-Advanta Company and ANRT. M. Stevens and H. G. Smith thank the Home Grown Sugar Beet (Research and Education) fund for financial support. M. Stevens and O. Lemaire were recipients of BBSRC/INRA fellowships. We thank G. C. Wisler (USDA, Salinas, CA) for supplying the American isolates and for helpful discussions in the course of this work; F. Rabenstein and J. Schubert (Aschersleben, Germany) for gifts of MAb G4C10, MAb $3 \mathrm{C} 2$, and German rape isolates; and M. T. Simonis for expert technical assistance in virus transmission and ELISA tests.

\section{LITERATURE CITED}

1. Chalhoub, B. A., and Lapierre, H. D. 1995. Importance des recombinaisons ARN dans l'évolution des lutéovirus. Agronomie 15:393-400.

2. D'Arcy, C. J., and Mayo, M. A. 1997. Proposals for changes in luteovirus taxonomy and nomenclature. Arch. Virol. 142:1285-1287.

3. D'Arcy, C. J., Torrance, L., and Martin, R. R. 1989. Discrimination among luteoviruses and their strains by monoclonal antibodies and identification of common epitopes. Phytopathology 79:869-873.

4. de Miranda, J. R., Stevens, M., de Bruyne, E., Smith, H. G., Bird, C., and Hull, R. 1995. Beet luteovirus coat protein sequence variation. Ann. Appl. Biol. 127:113-124.
5. de Miranda, J. R., Stevens, M., de Bruyne, E., Smith, H. G., Bird, C., and Hull, R. 1995. Sequence comparison and classification of beet luteovirus isolates. Arch. Virol. 140:2183-2200.

6. Devereux, J., Haeberli, P., and Smithies, O. 1984. A comprehensive set of sequence analysis programs for the VAX. Nucleic Acids Res. 12:387-395.

7. Duffus, J. E. 1960. Radish yellows, a disease of radish, sugar beet, and other crops. Phytopathology 50:389-394.

8. Duffus, J. E. 1973. The yellowing viruse diseases of beet. Adv. Virus Res. 18:347-386.

9. Duffus, J. E., and Russell, G. E. 1970. Serological and host range evidence for the occurrence of beet western yellows virus in Europe. Phytopathology 60:1199-1202.

10. Duffus, J. E., and Russell, G. E. 1975. Serological relationship between beet western yellows and beet mild yellowing viruses. Phytopathology 65:811-815.

11. Ellis, P. J., and Wieczorek, A. 1992. Production of monoclonal antibodies to beet western yellows virus and potato leafroll virus and their use in luteovirus detection. Plant Dis. 76:75-78.

12. Erokhina, T., and Kastalieva, T. 1995. Production of monoclonal antibodies against barley yellow dwarf virus. Detection of BaYDV in the field samples from central region of Russia. 75 years of phytopathological and resistance research at Aschersleben. Ber. Bundesanst. Züchtungsforsch. Kulturpflanzen 1:71-74.

13. Felsenstein, J. 1989. PHYLIP-Phylogeny interference package (version 3.2). Cladistics 5:164-166.

14. Gibbs, M. 1995. The luteovirus supergroup: Rampant recombination and persistent partnerships. Pages 351-368 in: Molecular Basis of Virus Evolution. A. J. Gibbs, C. H. Callisher, and F. Garcia-Arenal, eds. Cambridge University Press, Cambridge.

15. Govier, D. A. 1985. Purification and partial characterisation of beet mild yellowing virus and its serological detection in plants and aphids. Ann. Appl. Biol. 107:439-447.

16. Graichen, K., and Rabenstein, F. 1996. European isolates of beet western yellows virus (BWYV) from oilseed rape (Brassica napus L. ssp. napus) are non-pathogenic on sugar beet (Beta vulgaris L. var. altissima) but represent isolates of turnip yellows virus (TuYV). J. Plant Dis. Prot. 103: 233-245.

17. Guilley, H., Richards, K., and Jonard, G. 1995. Nucleotide sequence of beet mild yellowing virus RNA. Arch. Virol. 140:1109-1118.

18. Hampton, R. O., Keller, K. E., and Baggett, J. R. 1998. Beet western yellows luteovirus in western Oregon. Pathosystem relationships in a vegetable-sugar beet seed production region. Plant Dis. 82:140-148.

19. Herrbach, E., Lemaire, O., Ziegler-Graff, V., Lot, H., Rabenstein, F., and Bouchery, Y. 1991. Detection of BMYV and BWYV isolates using monoclonal antibodies and radioactive RNA probe, and relationships among luteoviruses. Ann. Appl. Biol. 118:127-138.

20. Kotewicz, M. L., Sampson, C. M., D’Alessio, J. M., and Gerard, G. F. 1988. Isolation of cloned Moloney murine leukemia virus reverse transcriptase lacking ribonuclease $\mathrm{H}$ activity. Nucleic Acids Res. 16:265-277.

21. Lemaire, O., Herrbach, E., Stevens, M., Bouchery, Y., and Smith, H. G. 1995. Detection of sugar beet-infecting beet mild yellowing luteovirus isolates with a specific RNA probe. Phytopathology 85:1513-1518.

22. Lewellen, R. T., Wisler, G. C., Liu, H.-Y., Kaffka, S. R., Sears, J. L., and Duffus, J. E. 1999. Reaction of sugarbeet breeding lines and hybrids to beet chlorosis luteovirus. J. Sugar Beet Res. 36:76.

23. Liu, H.-Y., Wisler, G. C., Sears, J. L., and Duffus, J. E. 1999. Beet chlorosis virus-A new luteovirus affecting sugarbeet. J. Sugar Beet Res. 36:69.

24. Mayo, M. A., Robinson, D. J., Jolly, C. A., and Hymann, L. 1989. Nucleotide sequence of potato leafroll virus RNA. J. Gen. Virol. 70:1037-1051.

25. Mayo, M. A., and Ziegler-Graff, V. 1996. Molecular biology of luteoviruses. Adv. Virus Res. 46:413-460.

26. Oshima, K., and Shikata, E. 1990. On the screening procedures of ELISA for monoclonal antibodies against three luteoviruses. Ann. Phytopathol. Soc. Jpn. 56:219-228.

27. Peters, D. 1988. A conspectus of plant species as host for viruses causing beet yellows diseases. Pages 87-117 in: Virus Yellows Monograph. I.I.R.B. Pests and Diseases Study Group, Brussels.

28. Rabenstein, F., Graichen, K., Proll, E., Herrbach, E., and Lemaire, O. 1995. Detection of a second distinct strain of beet western yellows luteovirus in oilseed rape using monoclonal antibodies. Ber. Bundesanst. Züchtungsforsch. Kulturpflanzen 1:137-140.

29. Russell, G. E. 1958. Sugar beet yellows: A preliminary study of the distribution and interrelationships of viruses and virus strains found in East Anglia, 1955-1957. Ann. Appl. Biol. 46:393-398.

30. Saiki, R. K., Gelfand, D. H., Stoffel, S., Sharf, S. J., Higuchi, R., Horn, G. T., Mullis, K. B., and Erlich, H. A. 1988. Primer-directed enzymatic amplification of DNA with a thermostable DNA polymerase. Science 239:487-491.

31. Saitou, N., and Nei, M. 1987. The neighbor-joining method: A new 
method for reconstructing phylogenetic trees. Mol. Biol. Evol. 4:406-425.

32. Schubert, J., Rabenstein, F., Graichen, K., and Richter, K. 1998. Comparison of the $5^{\prime}$-end nucleotide sequences of luteoviruses from oilseed rape and sugar beet. Arch. Phytopathol. Pflanzenschutz 31:519-530.

33. Smith, H. G., Barker, I., Brewer, G., Stevens, M., and Hallsworth, P. B. 1996. Production and evaluation of monoclonal antibodies for the detection of beet mild yellowing luteovirus and related strains. Eur. J. Plant Pathol. 102:163-169.

34. Smith, H. G., Stevens, M., and Hallsworth, P. B. 1991. The use of monoclonal antibodies to detect beet mild yellowing virus and beet western yellows virus in aphids. Ann. Appl. Biol. 119:295-302.

35. Stevens, M., Dolby, C. A., and Smith, H. G. 1997. Comparison of properties of European isolates of BMYV and BYV. Pages 561-564 in: Proc. 60th IIRB Congr. I.I.R.B., Brussels.

36. Stevens, M., Smith, H. G., and Hallsworth, P. B. 1994. The host range of beet yellowing viruses among common arable weed species. Plant Pathol. 43:579-588.

37. Stevens, M., Smith, H. G., and Hallsworth, P. B. 1994. Identification of a second distinct strain of beet mild yellowing luteovirus using monoclonal antibodies and transmission studies. Ann. Appl. Biol. 125:515-520.

38. Thompson, J. D., Gibson, T. J., Plewniack, F., Jeanmougin, F., and Higgins, D. G. 1997. The ClustalX windows interface: Flexible strategies for multiple sequence alignment aided by quality analysis tools. Nucleic Acids Res. 24:4876-4882.

39. van der Wilk, F., Houterman, P., Molthoff, J., Hans, F., Dekker, B., van den Heuvel, J., Huttinga, H., and Goldbach, R. 1997. Expression of the potato leafroll virus ORF0 induces viral-disease-like symptoms in transgenic potato plants. Mol. Plant-Microbe Interact. 10:153-159.

40. Veidt, I., Bouzoubaa, S. E., Leiser, R. M., Ziegler-Graff, V., Guilley, H., Richards, K., and Jonard, G. 1992. Synthesis of full-length transcripts of beet western yellows virus RNA: Messenger properties and biological activity in protoplasts. Virology 186:192-200.

41. Veidt, I., Lot, H., Leiser, M., Scheidecker, D., Guilley, H., Richards, K., and Jonard, G. 1988. Nucleotide sequence of beet western yellows virus RNA. Nucleic Acids Res. 16:9917-9932.

42. Waterhouse, P. M., Gildow, F. E., and Johstone, G. R. 1988. Luteovirus group. Pages 339-347 in: Descriptions of Plant Viruses. Commonw. Mycol. Inst./Assoc. Appl. Biol., Kew, England. 